\title{
THE METABOLIC RESPONSE TO PENTAZOCINE AS A SUPPLEMENT TO BALANCED ANAESTHESIA FOR MAJOR ABDOMINAL SURGERY*
}

Allen B. Dobkin, M.D., Jacob S. Israel, m.D., and Pauline A. Pieloch, m.d.

Pentazocine ( Talwin ${ }^{\circledR}$ ) is the $\mathrm{N}$-dimethylallyl analogue of phenazocine. It has weak narcotic antagonistic effects as well as moderately strong analgesic properties when given either by mouth or parenterally. ${ }^{1}$ During the past five years, pentazocine has undergone clinical trials and appears to provide satisfactory analgesia in a broad range of pain syndromes. ${ }^{2-4}$ Originally, the dose recommended for parenteral administration was two to three times that of morphine ${ }^{5}$ but, with more experience, it appeared that three to five times was a more realistic requirement. This higher dose level had some disadvantages. ${ }^{6}$

Following a careful study in animals and in human volunteers, ${ }^{7-10}$ it appeared to us that pentazocine might be useful as a supplement to balanced anaesthesia because it was claimed that it seldom caused addiction, and both respiratory depression and psychic side effects were not prominent. ${ }^{11-14}$ This report deals with our clinical evaluation of pentazocine as a supplement to balanced anaesthesia for major abdominal surgery in relatively poor-risk patients.

\section{Clinical management}

\section{Materials AND Methods}

Informed consent for the study was obtained from each patient. Premedication was with atropine $0.3 \mathrm{mg}$ and scopolamine $0.3 \mathrm{mg}$ subcutaneously one hour before surgery. Upon arrival in the operating room, blood samples were drawn, an electrocardiogram recording taken, and an intravenous infusion of lactated Ringer's solution started.

After vital signs were obtained and recorded, 30 patients were induced with repeated serial intravenous injections of $30 \mathrm{mg}$ pentazocine at one- to two-minute intervals. When an alteration in vital signs (respiration, blood pressure or state of awareness) indicated drug effect, nitrous oxide-oxygen (2-3:1) by face mask was introduced until the patient was judged to be anaesthetized. Succinylcholine (100 mg) was then administered intravenously and endotracheal intubation was accomplished. The patient was then connected to a mechanical respirator set to produce a tidal volume of $10 \mathrm{ml} / \mathrm{kg}$ at a rate of 15 to 18 per minute. During maintenance, pentazocine was administered intravenously in $30 \mathrm{mg}$ increments. A dilute infusion of succinylcholine ( 0.1 per cent) was used to maintain muscle relaxation. Whole blood or packed red cells and electrolyte infusions were administered as indicated. No dextrose solution was given. Pentazocine and succinylcholine administration were discontinued as soon as the abdominal fascia was closed.

'From the Department of Anesthesiology, State University Hospital, State University of New York, Upstate Medical Center, Syracuse, New York.

485

Canad. Anaesth. Soc. J., vol. 17, no. 5, September 1970 
An additional 38 patients were induced with a "sleep" dose of thiopental and maintained with pentazocine, as in the first group.

\section{Clinical monitoring and follow-up}

Auscultatory blood pressure and pulse rate were recorded every five minutes; rectal temperature was monitored with a thermister probe and recorded every 10 to 15 minutes. The ECG was monitored on an oscillograph and tracings were made with a direct-writer before and during induction, during intubation, and at intervals during anaesthesia and recovery. Urinary output was recorded in patients whose bladder was catheterized.

Postoperatively, respiratory rate and minute volume were measured with a Wright respirometer for one hour. Recovery of wakefulness was determined by noting the time when the patient opened his eyes and protruded his tongue on command.

During the first 24 hours after anaesthesia, each patient was observed closely, and records were kept to determine the incidence of side effects and complications. The occurrence of amnesia for the period in the operating room was checked by a questionnaire, and the amount of narcotic pain medication received was recorded.

\section{Laboratory studies}

Arterial blood samples were draw and analyzed the day before surgery, just prior to induction (one hour after premedication), at hourly intervals during anaesthesia, at the end of surgery, then 30 minutes, 60 minutes, and 24 hours after the end of anaesthesia. Analyses were carried out in duplicate with a $\mathrm{pH}$ electrode, a Clark electrode for measuring oxygen tension, and a Severinghaus electrode for measuring carbon dioxide tension at $37^{\circ} \mathrm{C}$. Oxyhaemoglobin saturation was measured on an American Optical reflection oximeter. Haematocrit was measured by a micro-method. Plasma bicarbonate concentration was derived from the $\mathrm{pH}$ and $\mathrm{Pa}_{\mathrm{CO}_{2}}$. Haemoglobin concentration was determined with cyanmethemoglobin standard solutions. Oxygen content in volumes per $100 \mathrm{ml}$ was calculated from the product of the haemoglobin $\mathrm{gm} / 100 \mathrm{ml} \times$ oxygen saturation $\times 0.0139$.

The following laboratory estimations were done on venous blood samples taken before and 30 minutes after anaesthesia: plasma cortisol by the fluorescent method of Mattingly ${ }^{15}$ plasma histamine by a modification of the method of Noah and Brand, ${ }^{16}$ whole blood serotonin by the method of Udenfriend, Weissbach and Brodie, ${ }^{17}$ and plasma catecholamines by the method of Anton and Sayre. ${ }^{18}$ Serum sodium, potassium, and calcium, transaminases (SGOT and SGPT), blood urea nitrogen, creatinine, bilirubin, and glucose were measured by standard laboratory procedures. Differential white blood counts and urinalyses were done routinely before and as required after anaesthesia. Laboratory data were analysed statistically to determine whether significant alterations accurred.

\section{Clinical observations}

\section{ResUlts AND Discussion}

Data were collected from anaesthetics administered to 68 patients, of whom 30 were induced with pentazocine (group A) and 38 with thiopental intravenously 
(group B). The groups were statistically comparable as to age, sex, physical status, and duration of operation (Table I).

Pentazocine can be used as a supplement in a balanced technique, but in doses which are many times greater than those recommended for analgesia. In group A, respiratory rate depression was precipitous during induction - in some cases to the point of apnoea, without adequate hypnosis being apparent. The hypnotic dose was usually associated with the appearance of nystagmus, which coincided with the onset of amnesia, and was the best indicator for beginning the administration of nitrous oxide-oxygen. Because of the large doses of pentazocine required to produce an adequate level of hypnosis, we decided after the first 30 cases that anaesthesia should be induced with thiopental.

\section{Comparison of drug dosage (Table I)}

During induction, $166 \pm 85 \mathrm{mg}$ ( or $2.4 \pm 1.0 \mathrm{mg} / \mathrm{kg}$ ) of pentazocine was used in group $\mathrm{A}$, while approximately $325 \pm 75 \mathrm{mg}$ of thiopental was used in group $\mathrm{B}$. While thiopental induced "sleep" in every case, nitrous oxide was required to accomplish this when pentazocine was employed. During maintenance, only a small additional amount of pentazocine was required. The total dose being $1.8 \pm 0.7 \mathrm{mg} /$ $\mathrm{min}$ in group $\mathrm{A}$ and $1.6 \pm 0.54 \mathrm{mg} / \mathrm{min}$ in group $\mathbf{B}$. Thus, induction with thiopental did not appreciably reduce the requirement for pentazocine. However, anaesthesia was judged much smoother in the thiopental-induced group.

The maintenance dose of succinylcholine in group A averaged $2.7 \pm 1.3 \mathrm{mg} /$ min and, in group B, $2.9 \pm 1.0 \mathrm{mg} / \mathrm{min}$ - an insignificant difference.

TABLE I

Summary of Vital Data of Patients Studied with Pentazocine

\begin{tabular}{lcc}
\hline & \multicolumn{2}{c}{ Pentazocine- ${ }_{2} \mathrm{O}-$ Succinylcholine } \\
\cline { 2 - 3 } & group A & group B \\
\hline No. of patients & 30 & 38 \\
male & 11 & 17 \\
female & 19 & 21 \\
age range & $21-80$ & $24-85$ \\
mean age & 57 & 56 \\
ASA II & 18 & 23 \\
ASA III & 12 & 15 \\
Duration of anaesthesia (mean) & $174 \mathrm{~min}$. & $192 \mathrm{~min}$. \\
Duration range & $70-270$ & $80-390$ \\
Thiopental induction & 0 & $318 \pm 76 \mathrm{mg}$. \\
Succinylcholine induction & $100 \mathrm{mg}$. & $100 \mathrm{mg}$. \\
Succinylcholine maintenance & $2.7 \pm 1.3 \mathrm{mg} . / \mathrm{min}$. & $2.9 \pm 1.0 \mathrm{mg} . / \mathrm{min}$. \\
Pentazocine & $1.8 \pm 0.7 \mathrm{mg} . / \mathrm{min}$. & $1.6 \pm 0.5 \mathrm{mg} . / \mathrm{min}$. \\
\hline
\end{tabular}

Blood pressure and pulse rate (Table II)

During induction of anaesthesia, group в tended to have a modest reduction in systolic and pulse pressures. Both groups demonstrated a consistent rise in systolic and diastolic pressures during maintenance of anaesthesia, with a return to control levels within 60 minutes of the end of anaesthesia. The rise in blood pressure during maintenance in group B appeared later than in group A. The pulse rate remained steady and often rose during recovery. 
One elderly female patient scheduled for cholecystectomy, in whom induction of anaesthesia was attempted with pentazocine developed progressive, severe hypertension, which led to a grand mal convulsion. Succinylcholine, intubation, and hyperventilation with oxygen arrested the convulsion promptly, but the blood pressure remained very high (280/140); addition of halothane reduced it only during inhalation. It was necessary to administer Regitine to ensure a reasonable blood pressure. The operation was cancelled and a thorough physical and biochemical investigation of all possible causes of the hypertension did not reveal any explanation other than an idiosyncrasy to pentazocine.

TABLE II

Changes in Blood Pressure and Pulse Rate

\begin{tabular}{|c|c|c|c|c|c|c|c|c|c|c|c|c|c|c|c|}
\hline \multicolumn{16}{|c|}{ With Pentazocine- $\mathrm{N}_{2} \mathrm{O}$-Succinylcholine Anaesthesia (30 patients) } \\
\hline & \multicolumn{3}{|c|}{$\begin{array}{c}\text { Before } \\
\text { induction }\end{array}$} & \multicolumn{3}{|c|}{$\begin{array}{c}20 \text { minutes } \\
\text { after }\end{array}$} & \multicolumn{3}{|c|}{$\begin{array}{c}\text { End of } \\
\text { anaesthesia }\end{array}$} & \multicolumn{3}{|c|}{$\begin{array}{l}30 \text { minutes } \\
\text { after }\end{array}$} & \multicolumn{3}{|c|}{$\begin{array}{l}60 \text { minutes } \\
\text { after }\end{array}$} \\
\hline & $\mathrm{s}$ & $D$ & $P$ & $\mathrm{~s}$ & $\mathrm{D}$ & $\mathbf{P}$ & s & $\mathrm{D}$ & $\mathrm{P}$ & $s$ & $\mathrm{D}$ & $\mathbf{P}$ & $\mathrm{s}$ & D & $\mathbf{P}$ \\
\hline Mean & 149 & 89 & 93 & 159 & 99 & 89 & 157 & 95 & 88 & 156 & 90 & 88 & 149 & 86 & 94 \\
\hline S.E.M. & 5 & 3 & 3 & 5 & 3 & 2 & 4 & 2 & 2 & 5 & 3 & 2 & 5 & 2 & 2 \\
\hline
\end{tabular}

With Thiopentone- ${ }_{2} \mathrm{O}-$ Pentazocine-Succinylcholine ( 38 patients)

\begin{tabular}{|c|c|c|c|c|c|c|c|c|c|c|c|c|c|c|c|}
\hline & \multicolumn{3}{|c|}{$\begin{array}{l}\text { Before } \\
\text { induction }\end{array}$} & \multicolumn{3}{|c|}{$\begin{array}{l}20 \text { minutes } \\
\text { after }\end{array}$} & \multicolumn{3}{|c|}{$\begin{array}{c}\text { End of } \\
\text { anaesthesia }\end{array}$} & \multicolumn{3}{|c|}{$\begin{array}{l}30 \text { minutes } \\
\text { after }\end{array}$} & \multicolumn{3}{|c|}{$\begin{array}{l}60 \text { minutes } \\
\text { after }\end{array}$} \\
\hline & $s$ & D & $\mathrm{P}$ & $\mathrm{s}$ & $\mathrm{D}$ & $\mathrm{P}$ & s & D & $\mathbf{P}$ & $\mathrm{s}$ & $\mathrm{D}$ & $\mathbf{P}$ & 5 & D & $\mathbf{P}$ \\
\hline Mean & 143 & 85 & 82 & 141 & 91 & 81 & 151 & 95 & 86 & 153 & 93 & 98 & 146 & 89 & 97 \\
\hline S.E.M. & 4 & 2 & 2 & 5 & 3 & 2 & 4 & 2 & 2 & 4 & 3 & 3 & 4 & 2 & 3 \\
\hline
\end{tabular}

$\mathrm{s}=$ Systolic blood pressure $\mathrm{mm} \mathrm{Hg}$.

$\mathrm{D}=$ Diastolic blood pressure $\mathrm{mm} \mathrm{Hg}$.

$\mathbf{P}=$ Pulse rate per minute.

\section{Electrocardiogram}

Minor variations of rhythm occurred during induction and intubation, but serious arrhythmias did not persist. In a few cases abnormal rhythms present preoperatively disappeared during anaesthesia. In all cases the electrocardiogram was stable during maintenance and emergence from anaesthesia.

\section{Recovery of wakefulness}

Twenty-two of 30 patients in group A, and 25 of 38 in group B were awake at the time of admission to the recovery room. During the first hour in the recovery room, six more patients in group A, and nine more in group B, had recovered wakefulness. Recovery time greater than one hour occurred in two ( 7 per cent) patients of group A and four ( 11 per cent) of group B. There did not appear to be any apparent difference in the alertness after recovery of wakefulness in the two groups, even though the patients in group $\mathbf{B}$ received thiopental during induction of anaesthesia. 
In 15 of the 21 patients who did not awaken promptly ( $<10$ minutes), unconsciousness was associated with marked respiratory depression (tidal volume 50 to $100 \mathrm{ml}$ ) despite evidence (blockade monitor) of the absence of neuromuscular block. The return of consciousness and spontaneous respiration tended to be abrupt, i.e., the patient would be unconscious and tolerate the respirator - then abruptly awaken, resist the respirator, and appear to have an adequate respiratory rate and tidal volume.

\section{Recovery of respiration (Table III)}

The mean minute volume at the end of anaesthesia, and 30 and 60 minutes following anaesthesia, was slightly greater than the average predicted minute volume derived from the Radford nomogram. The average value for respiratory rate was within the normal range.

Of those 21 patients not awake promptly after the discontinuance of nitrous oxide in the operating room, two in group $A$ and four in group B required assisted or controlled ventilation for more than 30 minutes. These six patients were recovering from an excessive amount of succinylcholine. All patients were breathing normally within one hour after surgery.

TABLE III

ReCOVERy of Respiration After ANAEsthesia

\begin{tabular}{|c|c|c|c|c|c|c|c|}
\hline \multicolumn{8}{|c|}{ With $\mathrm{N}_{2} \mathrm{O}$-Pentazocine-Succinylcholine ( 30 patients) } \\
\hline & \multirow{2}{*}{$\begin{array}{c}\text { Radford } \\
\text { predicted } \\
\text { min vol (L) }\end{array}$} & \multicolumn{2}{|c|}{ End of anaesthesia } & \multicolumn{2}{|c|}{30 minutes after } & \multicolumn{2}{|c|}{60 minutes after } \\
\hline & & rate $/ \mathrm{min}$ & $\mathrm{MV}(\mathrm{L})$ & $\mathrm{rate} / \mathrm{min}$ & $\operatorname{MV}(\mathrm{L})$ & $\mathrm{rate} / \mathrm{min}$ & $\mathrm{MV}(\mathrm{L})$ \\
\hline $\begin{array}{l}\text { Mean } \\
\text { S.D. } \\
\text { S.E.M. }\end{array}$ & $\begin{array}{l}6.38 \\
1.07 \\
0.20\end{array}$ & $\begin{array}{c}17 \\
4 \\
0.8\end{array}$ & $\begin{array}{l}7.0 \\
2.8 \\
0.6\end{array}$ & $\begin{array}{l}20 \\
3 \\
0.6\end{array}$ & $\begin{array}{l}7.9 \\
2.8 \\
0.5\end{array}$ & $\begin{array}{c}20 \\
5 \\
0.9\end{array}$ & $\begin{array}{l}8.6 \\
2.5 \\
0.5\end{array}$ \\
\hline
\end{tabular}

With Thiopental- $\mathrm{N}_{2} \mathrm{O}-$ Pentazocine-Succinylcholine (38 patients)

\begin{tabular}{|c|c|c|c|c|c|c|c|}
\hline & \multirow{2}{*}{$\begin{array}{c}\text { Radford } \\
\text { predicted } \\
\text { min vol (L) }\end{array}$} & \multicolumn{2}{|c|}{ End of anaesthesia } & \multicolumn{2}{|c|}{30 minutes after } & \multicolumn{2}{|c|}{60 minutes after } \\
\hline & & $\mathrm{rate} / \mathrm{min}$ & $\operatorname{MV}(\mathrm{L})$ & rate $/ \mathrm{min}$ & $\operatorname{Mv}(\mathrm{L})$ & $\mathrm{rate} / \mathrm{min}$ & $\operatorname{Mv}(\mathrm{L})$ \\
\hline $\begin{array}{l}\text { Mean } \\
\text { S.D. } \\
\text { S.E.M. }\end{array}$ & $\begin{array}{l}6.40 \\
1.17 \\
0.20\end{array}$ & $\begin{array}{l}20 \\
4 \\
0.9\end{array}$ & $\begin{array}{l}7.9 \\
2.4 \\
0.6\end{array}$ & $\begin{array}{c}20 \\
\mathbf{4} \\
0.8\end{array}$ & $\begin{array}{l}8.1 \\
2.9 \\
0.6\end{array}$ & $\begin{array}{l}20 \\
4 \\
0.8\end{array}$ & $\begin{array}{l}8.0 \\
2.2 \\
0.4\end{array}$ \\
\hline
\end{tabular}

\section{Nause and vomiting}

This side effect did not occur in an excessive number of cases, considering the type of surgery, and there was no difference between the two groups (27 per cent in group $\mathrm{A}$ and 26 per cent in group B). Symptoms developed in the first six hours in 13 per cent of group $A$ and in 17 per cent of group B. Recurrent symptoms occurred in 10 per cent of patients in group $A$ and in 11 per cent of those in group B. In approximately half of the patients who had nausea and vomiting postoperatively ( 13 per cent), the symptoms followed the administration of analgesic medication for relief of pain (see below). 


\section{Postoperative analgesia}

Twenty-seven patients in group a received postoperative analgesic medication; of these, 23 went more than four hours before receiving it. The frequency distribution of the number of injections for analgesia in the first 24 postoperative hours was similar for both groups. Twenty-three patients had two or fewer injections in group $\mathrm{A}$, while in group в 25 patients had two or fewer injections. This experience was the same as that seen after inhalation anaesthesia, although these patients appeared to be alert earlier.

\section{Other subjective data}

Most patients in group a arrived in the operating room alert. During the followup, many of them complained that going to sleep took a long time. Virtually all of the patients recalled, in detail, the events leading to going to sleep with the nitrous oxide. However, only a few admitted that the process was unpleasant. This concern over the time to sleep occurred despite our reassurance before and during induction that it was not expected to happen abruptly. One patient in this group had vague recollection of a pulling sensation during surgery. He also felt that the process of going to sleep was unpleasant and took much too long as compared with his previous experience.

Patients in group B were satisfied with the induction, but three of them vaguely recalled the oral intubation. Three other patients in this group described sensations consistent with consciousness during surgery, though the feelings were transient and not painful. The recollections seemed to be associated with surgical traction.

Although the preoperative medication was the same for all the patients, those in group B had a far higher incidence of total amnesia for events in the operating room. Even though this was not a programmed comparison, it appears as if thiopental, administered following scopolamine premedication, enhances retrograde amnesia.

\section{Laboratory observations (Tables IV and V)}

Both groups showed a rise in blood glucose, plasma cortisol, epinephrine, and norepinephrine levels after anaesthesia and surgery, which reflect a normal response to stress. The rise in tissue enzymes (SGOT, SGPT) in both groups was within the range commonly associated with abdominal surgery and anaesthesia, and did not indicate any specific abnormality. The remaining metabolic parameters were not significantly altered from control levels.

\section{Acid-base status (Tables VI and VII)}

There was no significant difference between the two groups with respect to respiratory management, fluid balance, and blood replacement. Both groups were maintained in an essentially stable condition for the first 24 hours after operation.

The mean $\mathrm{Pa}_{\mathrm{O}_{2}}$ during and at the end of anaesthesia reflected the inhaled gas mixture. Later, spontaneous respiration with room air gave $\mathrm{Pa}_{\mathrm{O}_{2}}$ values ranging from $72 \mathrm{~mm} \mathrm{Hg}$ before surgery to $60 \mathrm{~mm} \mathrm{Hg}$ after surgery - reflecting the pre- 
TABLE IV

Metabolic Changes during Anaesthesia

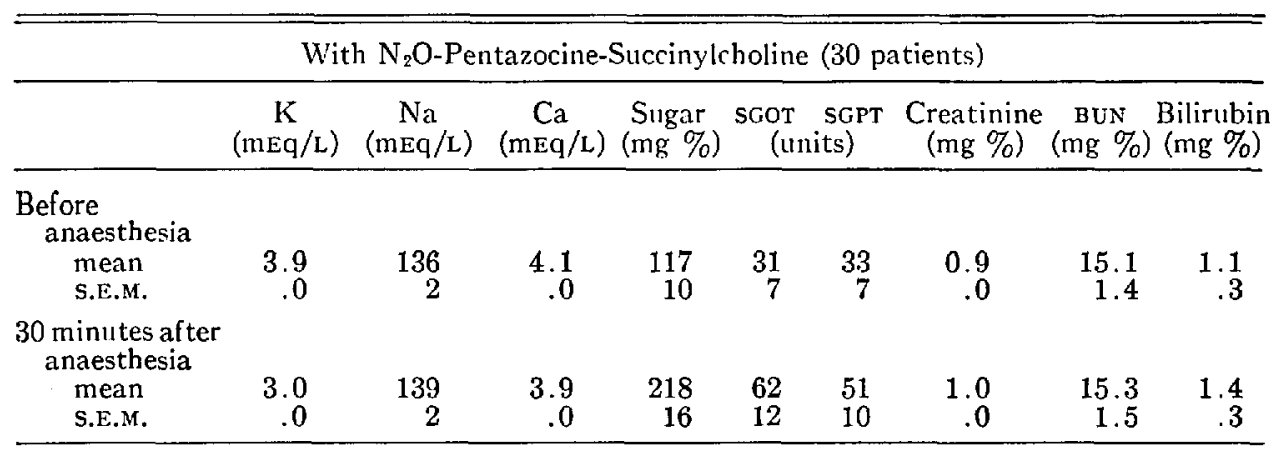

With Thiopentone- $\mathrm{N}_{2} \mathrm{O}$-Pentazocine-Succinylcholine ( 38 patients)

\begin{tabular}{|c|c|c|c|c|c|c|c|c|c|}
\hline & $\begin{array}{c}\mathrm{K} \\
(\mathrm{mEq} / \mathrm{L})\end{array}$ & $\begin{array}{c}\mathrm{Na} \\
(\mathrm{mEq} / \mathrm{L})\end{array}$ & $\begin{array}{c}\mathrm{Ca} \\
(\mathrm{mEq} / \mathrm{L})\end{array}$ & $\begin{array}{c}\text { Sugar } \\
(\mathrm{mg} \%)\end{array}$ & $\begin{array}{r}\text { SGOT } \\
\quad(\mathrm{u} \\
\end{array}$ & $\begin{array}{l}\text { SGPT } \\
\text { (iits) }\end{array}$ & $\begin{array}{c}\text { Creatinine } \\
(\mathrm{mg} \%)\end{array}$ & $\begin{array}{c}\text { BuN } \\
(\mathrm{mg} \%)\end{array}$ & $\begin{array}{c}\text { Bilirubin } \\
(\mathrm{mg} \mathrm{\% )}\end{array}$ \\
\hline $\begin{array}{l}\text { Before } \\
\text { anaesthesia } \\
\text { mean } \\
\text { S.E.M. }\end{array}$ & $\begin{array}{r}3.8 \\
.1\end{array}$ & $\begin{array}{r}136 \\
1\end{array}$ & $\begin{array}{r}4.3 \\
.1\end{array}$ & $\begin{array}{r}119 \\
9\end{array}$ & $\begin{array}{r}44 \\
9\end{array}$ & $\begin{array}{l}52 \\
14\end{array}$ & $\begin{array}{r}0.9 \\
.0\end{array}$ & $\begin{array}{r}14.0 \\
1.1\end{array}$ & $\begin{array}{l}2.3 \\
0.8\end{array}$ \\
\hline $\begin{array}{l}30 \text { minutes after } \\
\text { anaesthesia } \\
\text { mean } \\
\text { S.E.M. }\end{array}$ & $\begin{array}{r}2.9 \\
.1\end{array}$ & $\begin{array}{r}135 \\
1\end{array}$ & $\begin{array}{r}3.9 \\
.1\end{array}$ & $\begin{array}{r}248 \\
1.8\end{array}$ & $\begin{array}{l}77 \\
10\end{array}$ & $\begin{array}{l}69 \\
14\end{array}$ & $\begin{array}{r}1.0 \\
.0\end{array}$ & $\begin{array}{r}13.1 \\
1.1\end{array}$ & $\begin{array}{l}2.5 \\
0.7\end{array}$ \\
\hline
\end{tabular}

TABLE V

Metabolic Changes during Anaesthesia

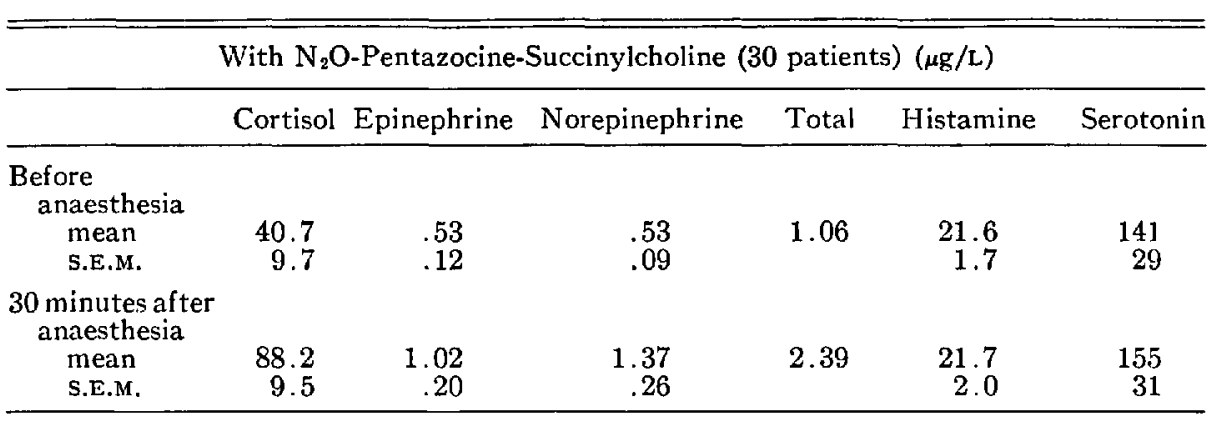

With Thiopentone- $\mathrm{N}_{2} \mathrm{O}$-Pentazocine-Succinylcholine (38 patients) $(\mu \mathrm{g} / \mathrm{L}$ )

\begin{tabular}{|c|c|c|c|c|c|c|}
\hline & Cortisol & Epinephrine & Norepinephrine & Total & Histamine & Serotonin \\
\hline \multicolumn{7}{|l|}{$\begin{array}{l}\text { Before } \\
\text { anaesthesia }\end{array}$} \\
\hline mean & 35.4 & .83 & 1.06 & 1.89 & 19.7 & 181 \\
\hline S.E.M. & 4.3 & .23 & .18 & & 1.8 & 27 \\
\hline \multicolumn{7}{|l|}{30 minutes after } \\
\hline mean & 82.0 & 2.07 & 2.48 & 4.55 & 19.9 & 178 \\
\hline S.E.M. & 9.4 & .49 & .45 & & 2.1 & 23 \\
\hline
\end{tabular}


TABLE VI

Blood Gas Data in Patients Induced with Pentazocine*

\begin{tabular}{|c|c|c|c|c|c|c|c|c|}
\hline & & $\mathrm{pH}$ & $\underset{(\mathrm{mm} \mathrm{Hg})}{\mathrm{PaCO}_{2}}$ & $\begin{array}{l}\mathrm{HCO}_{3}^{-} \\
(\mathrm{mM} / \mathrm{L})\end{array}$ & $\begin{array}{l}\mathrm{Hct} \\
(\%)\end{array}$ & $\underset{(\mathrm{mm} \mathrm{Hg})}{\mathrm{PaO}_{2}}$ & $\begin{array}{l}\mathrm{Sa}_{2} \\
(\%)\end{array}$ & $\begin{array}{l}\mathrm{Hgb} \\
\mathrm{gm} \%\end{array}$ \\
\hline $\begin{array}{l}\text { Control } \\
\text { (day before) SR } \\
\text { Preanaesthetic } \\
\text { (after }\end{array}$ & $\begin{array}{l}\text { Mean } \\
\text { S.D. } \\
\text { Mean }\end{array}$ & $\begin{array}{r}7.45 \\
.04 \\
7.45\end{array}$ & $\begin{array}{r}35.4 \\
7.7 \\
33.2\end{array}$ & $\begin{array}{r}23.5 \\
5.0 \\
21.7\end{array}$ & $\begin{array}{r}41 \\
5 \\
41\end{array}$ & $\begin{array}{l}72 \\
18 \\
68\end{array}$ & $\begin{array}{r}97 \\
2 \\
96\end{array}$ & 16.7 \\
\hline $\begin{array}{l}\text { premedication) SR } \\
\text { During anaesthesia } \\
\text { (hourly mean) } \mathrm{CR}\end{array}$ & $\begin{array}{l}\text { S.D. } \\
\text { Mlean } \\
\text { S.D. }\end{array}$ & $\begin{array}{l}.03 \\
7.49 \\
.08\end{array}$ & $\begin{array}{r}4.9 \\
27.0 \\
7.9\end{array}$ & $\begin{array}{r}3.0 \\
19.5 \\
3.9\end{array}$ & $\begin{array}{r}5 \\
40 \\
7\end{array}$ & $\begin{array}{l}19 \\
90 \\
35\end{array}$ & $\begin{array}{r}2 \\
97 \\
2\end{array}$ & 2.2 \\
\hline End of anaesthesia & Mean & 7.37 & 38.8 & 20.7 & 40 & 213 & 99 & 16.1 \\
\hline$\left(100 \% \mathrm{O}_{2} \mathrm{SR}\right.$ & S.D. & .07 & 9.4 & 4.5 & 5 & 103 & 2 & 2.7 \\
\hline 30 minutes after & Mean & 7.38 & 37.1 & 20.8 & 40 & 70 & $9 \overline{4}$ & \\
\hline anaesthesia SR & S.D. & .07 & 9.5 & 4.4 & 5 & 28 & 4 & \\
\hline 60 minutes after & Mean & 7.38 & 37.8 & 20.8 & 41 & 68 & 94 & \\
\hline anaesthesia SR & $S . D$. & .06 & 8.9 & 4.1 & 5 & 26 & 5 & \\
\hline 24 hours after & Mean & 7.46 & 34.8 & 23.3 & 37 & 62 & 95 & \\
\hline anaesthesia SR & S.D. & .06 & 5.7 & 4.3 & 4 & 17 & 3 & \\
\hline
\end{tabular}

*Mean effect of anaesthesia with pentazocine- $\mathrm{N}_{2} \mathrm{O}$-succinylcholine (30 patients) on arterial blood gases.

TABLE VII

Blood Gas Data in Patients Induced with Thiopentone*

\begin{tabular}{|c|c|c|c|c|c|c|c|c|}
\hline & & $\mathrm{pH}$ & $\underset{(\mathrm{mm} \mathrm{Hg})}{\mathrm{PaCO}_{2}}$ & $\begin{array}{l}\mathrm{HCO}_{3}^{-} \\
(\mathrm{mM} / \mathrm{L})\end{array}$ & $\begin{array}{l}\mathrm{Hct} \\
(\%)\end{array}$ & $\begin{array}{c}\mathrm{PaO}_{2} \\
(\mathrm{~mm} \mathrm{Hg})\end{array}$ & $\begin{array}{l}\mathrm{SaO}_{2} \\
(\%)^{2}\end{array}$ & $\underset{\mathrm{gm} \%}{\mathrm{Hgb}}$ \\
\hline Control & Mean & 7.46 & 34.1 & 23.1 & 38 & 72 & 97 & \\
\hline $\begin{array}{l}\text { (day before) SR } \\
\text { Preanaesthetic }\end{array}$ & $\begin{array}{l}\text { S.D. } \\
\text { Mean }\end{array}$ & $\begin{array}{l}.05 \\
7.44\end{array}$ & $\begin{array}{r}4.5 \\
33.9\end{array}$ & $\begin{array}{r}3.1 \\
22.2\end{array}$ & $\begin{array}{r}5 \\
39\end{array}$ & $\begin{array}{l}12 \\
69\end{array}$ & 97 & 14.8 \\
\hline tion) $\mathrm{SR}$ & & .2 & & 3 & 5 & 14 & 2 & 2. \\
\hline During an & $\mathrm{Me}$ & 7.4 & & 19 & 38 & & $9 \overline{7}$ & \\
\hline & & .08 & 4 & 3. & 4 & 31 & 1 & \\
\hline End of anaesthesia & Mean & 7.37 & 36.9 & 19.8 & 37 & 281 & 99 & 14.0 \\
\hline$\left(100 \% \mathrm{O}_{2}\right) \mathrm{SR}$ & S.D & & 9.1 & 2.8 & 5 & 108 & 1 & 18 \\
\hline 30 minutes after & Mea & 7.36 & 37.3 & 20.3 & 38 & 66 & 94 & \\
\hline an & S.D. & .06 & 6.5 & 2. & $\begin{array}{r}5 \\
28\end{array}$ & 20 & 3 & \\
\hline fter & $\mathrm{Me}$ & 7.37 & 37.8 & 20.3 & 38 & 64 & 95 & \\
\hline ana & S.L & .07 & 8.4 & 2.5 & 6 & 16 & 3 & \\
\hline 24 hol & & 7.4 & 35 & 23. & 35 & 60 & 94 & \\
\hline anaesthesia SR & S.D & 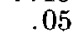 & & 2.0 & 6 & 16 & 2 & \\
\hline
\end{tabular}

*Mean effect of anaesthesia with thiopental- $\mathrm{N}_{2} \mathrm{O}$-pentazocine-succinylcholine (38 patients).

dominance of the older age group. The somewhat lower postoperative $\mathrm{Pa}_{\mathrm{O}_{2}}$ indicates the effect of complete bed rest as well as some increase in ventilation/ perfusion maldistribution in the lungs following major abdominal surgery.

The mean $\mathrm{Pa}_{\mathrm{CO}_{2}}$ was within the normal range in both groups throughout the studies, except for the mild respiratory alkalosis due to mechanical ventilation.

\section{COMMENT}

Pentazocine had a definite tendency to raise the systolic and diastolic blood pressures, and perhaps also to increase the pulse rate. While this study showed no deleterious effects on patients assumed to have reduced cardiac reserve, any increase in peripheral resistance - as indicated by a rise in diastolic pressure - 
cannot be ignored, particularly when considering this technique for the poor-risk patient. Moreover, the elevation of blood pressure deprived us of a supplementary sign for evaluating the adequacy of hypnosis and analgesia during surgery, adding to the difficulty of ensuring complete sensory and psychic deprivation for the patient.

One patient had a grand mal convulsion, probably secondary to the development of severe hypertension. Whether or not this is a rare occurrence is worthy of special reporting in man, for there are already claims and counter-claims as to the safety of this drug, especially in large dosages. ${ }^{13-17}$

\section{SUMmary AND Conclusions}

Pentazocine was employed as a supplement to nitrous oxide and succinylcholine for major abdominal surgery in two similar groups of adult patients who differed only in that one group received thiopental for induction of anaesthesia.

It was difficult to judge the onset of a hypnotic effect with pentazocine during induction, although once nystagmus appeared the patient had reached the stage of amnesia. Pentazocine caused a moderate but definite steady elevation of both systolic and diastolic blood pressures throughout surgery, which made it difficult to determine whether adequate anaesthesia existed. However, analgesia was always present. One patient (out of 68) had severe hypertension and a grand mal seizure during induction with pentazocine. If the systolic blood pressure rises more than 25 per cent above the resting level during administration of pentazocine, its use should be abandoned.

Based on these observations, we believe that the use of pentazocine in balanced anaesthesia with or without thiopental induction is unsuitable for major abdominal surgery. Even though the patients awakened rapidly, resumed adequate spontaneous respiration early in most cases, and had benign recovery periods, the overall impression was that the patients were not happy with their anaesthetic. Many objected to the long induction period and several were uncomfortably aware, psychically, of the endotracheal tube and of the surgery, even though they felt no pain.

\section{RÉSUMÉ}

La pentazocine a été employée comme supplément à l'anesthésie au protoxyde d'azote et succinylcholine pour des grandes opérations abdominales dans deux groupes similaires des malades adultes. La seule différence etait que dans un groupe l'induction se faisait au thiopental.

Il était difficile de juger le début de l'éffet hypnotique avec la pentazocine pendant l'induction, bien que, dès que le nystagmus apparaissait, le malade a atteint l'état d'amnésie. La pentazocine produisait une élévation modérée mais constante de la pression artérielle systolique et diastolique pendant toute l'intervention ce qui rendait difficile de déterminer si l'anesthésie était adéquate. Mais l'analgésie était toujours présente. Une malade (sur 68) manifestait une sévère élévation de la pression artérielle et des convulsions, type grand mal, pendant l'induction à la pentazocine. Si la pression systolique monte 25 pour cent au dessus de la 
normale pendant l'administration de pentazocine son utilisation doit être abandonnée.

L'emploi de la pentazocine dans l'anesthésie "balancée," avec ou sans induction au thiopental, n'est pas une méthode conventable pour des grandes opérations abdominales. Bien que les malades se réveillaient rapidement, bientôt reprenaient une respiration spontanée adéquate dans la majorité des cas et avaient une période postoperatoire banale; l'impression générale était que les malades n'étaient pas satisfaits de leur anesthésie.

Beaucoup d'eux reprochaient la longue période d'induction, certains avaient connaissance de l'intervention chirurgicale et de la présence du tube endotrachéal, bien qu'ils n'avaient pas de sensation de douleur.

\section{ACKNOWLEDGMENT}

Pentazocine (Talwin ${ }^{\circledR}$ ) was supplied by Doctor M. E. Trout of Winthrop Laboratories, New York City.

\section{REFERENCES}

1. Harris, L. S. \& PiErson, A. K. Some Narcotic Antagonists in Benzomorphan Series. J. Pharmacol. \& Exper. Therap. 143: 141 (1964).

2. Cass, L. J.; Frederuck, W. S.; \& Teodoro, J. V. Pentazocine as an Analgesic: Clinical Evaluation. J.A.M.A. 188: 112 (1964).

3. Sadove, M.; Balagot, R.; \& Pecora, F. Pentazocine: A New Non-addicting Analgesic: Preliminary Single Blind Study. J.A.M.A. 189: 199 (1964).

4. Gordon, R. A. \& Moran, J. H. Studies of Pentazocine (wIn 20,228): Evaluation as an Analgesic in Postoperative Patients. Canad. Anaesth. Soc. J. 12: 331 (1965).

5. Lasagna, L.; DeKonnfeld, T. J.; \& Pearson, J. W. The Analgesic Efficacy and Respiratory Effects in Man of a Benzomorphan "Narcotic Antagonist." J. Pharmacol. \& Exper. Therap. 144: 12 (1964).

6. Freedman, H.; Tafeen, C. H.; \& Harris, H. Parenteral wiv 20,228: An Analgesic in Labor. New York State J. Med. 67: 2849 (1967).

7. Dobkun, A. B. \& LeE, P. K. Y. Neuroleptanalgesics: 1. Effect of Droperidol, Fentanyl, Innovar, Benzquinamide and Pentazocine on the Duration of Thiopental-induced Sleep in Dogs. Canad. Anaesth. Soc. J. 12: 34 (1965).

8. DoBkIN, A. B.; LEE, P. K. Y.; \& BYLES, P. H. Neuroleptanalgesics: 2. Laboratory Evaluation of Combination of Analgesics and Neuroleptics with Nitrous Oxide. Canad. Anaesth. Soc. J. 12: 39 (1965).

9. Israei, J. S.; Jansen, G. T.; \& Dobkin, A. B. Circulatory and Respiratory Response to Tilt with Pentazocine (wIN 20,228), Droperidol (n4749), Droperidol-Fentanyl (Innovar) and Methotrimeprazine in Normal, Healthy Male Subjects. Anesthesiology. 26: 253 (1965).

10. Dobkin, A. B. \& Su, J. P-G. Newer Anesthetics and Their Uses. Clin. Pharmacol. \& Therap. 7: 648 (1966).

11. Fraser, H. F. \& Rosenberg, D. E. Studies on the Human Addiction Liability of 2hydroxy-5,9-dimethyl-2-(3,3-dimethyl allyl 6,7-benzomorphan (wIv 20,228): Weak Narcotic Antagonist. J. Pharmacol. \& Exper. Therap. 143: 149 (1964).

12. Keats, A. S. \& Telford, J. Studies of Analgesic Drugs: VIII. A Narcotic Antagonist Analgesic without Psychotomimetic Effects. J. Pharmacol. \& Exper. Therap. 143: 157 (1964).

13. Bellville, J. W. \& Green, J. The Respiratory and Subjective Effects of Pentazocine. Clin. Pharmacol. \& Therap. 6: 152 (1965).

14. Pentazocine (Talwin). The Medical Letter. 11: 41 (1969).

15. Neuschatz, J. Pentazocine: Massive Dosage Without Side-effects. J.A.M.A. 209: 112 (1969).

16. Sandoval, R. G. \& Wang, R. I. H. Tolerance and Dependence on Pentazocine. New England J. Med. 280: 1391 (1969).

17. HaRT, R. H. Pentazocine Addiction. Lancet. ii: 690 (1969). 